\title{
CONDITIONS FOR SUCCESSFUL DEVELOPMENT OF ELECTRONIC COMMERCE IN LATVIA
}

\author{
Sandra Ežmale \\ Rezeknes Augstskola, Faculty of Engineering, \\ Address: Atbrivosanas aleja 115, Rezekne, LV-4601, Latvia.
}

\begin{abstract}
The electronic commerce has become an integral part of the global economy during the last decade. The most obvious indication of the importance of electronic commerce in the world economy is rapidly increasing Internet use in trade and other sectors. The successful growth of e-commerce promotes the use of other electronic media, as well as it is perspective for development of territories located in backcountry and remote regions. In the result of the Internet and electronic commerce technological development there can be observed changes also in the business environment. In these circumstances successful strategies applied in different levels and sectors for the implementation of the most modern information technology achievements, as well as for the development of professionals with appropriate knowledge, expertise and skills, are becoming increasingly important for the development of electronic commerce in Latvia. The article will view the current situation, will explain the main limiting factors and advantages for successful development of the electronic commerce in Latvia.
\end{abstract}

Keywords: strategy, electronic commerce, policy framework.

\section{INTRODUCTION}

The electronic commerce has become an integral part of the global economy during the last decade. The most obvious indication of the important role of electronic commerce in the world economy is rapidly increasing Internet use in trade and other sectors. ICT and e-commerce are powerful tools that can improve productivity, increase efficiency, facilitate international trade, promote investments and contribute to the development of countries and regions.

Electronic commerce is often regarded as buying and selling using the Internet, but e- commerce involves much more than electronically mediated financial transactions between organizations and customers. Kalakota and Whinston [2] refer to a range of different perspectives for e- commerce:

- A communication perspective - the delivery of information, products/ services or payment by electronic means.

- A business process perspective - the application of technology towards the automation of business transactions and workflows.

- A service perspective - enabling cost cutting and at the same time increasing the speed and quality of service delivery.
- An online perspective - buying and selling products and information online [2].

Yürekli argues that e-commerce is production, advertisement, sale and distribution of goods and services on open network environment (internet) or via closed network environment (intranet). E-commerce has four parties as follows: enterprises, consumers, citizens and government. Moreover, interrelation of these parties in electronic environment forms four types of e-commerce. E-commerce, which brings innovations to economic structure in terms of commercial relations, affects many aspects of economic and social life. Working conditions, changes in consumer preferences, facilities in shopping, procedures in performing public duties, production costs, operational and market structure, competition, productivity, prices and employment can be given as the examples of the affected areas in parallel with the volume of e-commerce development [12]. In information society e-commerce helps to use resources more efficiently and reduce costs, providing significant advantages in price and enhancing competition and efficiency.

In these circumstances successful strategies applied in different levels and sectors for the implementation of the most modern information technology achievements, as well as for the development of professionals with appropriate knowledge, expertise and skills, are becoming increasingly important for the 
overall development of electronic commerce in Latvia.

The main goal is to view current situation and explain the main limiting factors and advantages for successful development of the electronic commerce in Latvia. This research deals with two tasks: (1) to investigate the development tendencies and limiting factors of electronic commerce in Latvia (enterprises, consumers, citizens and government); (2) to determine what strategies can be derived from the strategies of national level for the development of electronic commerce in order to bring a competitive advantage to e-businesses.

\section{DEVELOPMENT TENDENCIES OF ELECTRONIC COMMERCE IN LATVIA}

\section{E-commerce: government, citizens, consumers and} enterprises

In the period of the year 2009 to 2013 in Latvia there have been carried out diverse measures in the sphere of e-commerce in order to improve the efficiency of public administration and to provide convenient service receipt: there have been established electronic one-stop shops, there has been carried out the optimization of ICT infrastructure in the public administration, there has been promoted wider applicability of secure e-signature and there have been introduced electronic identification cards, furthered eservices, as well as developed public infrastructure necessary for provision of e-services.

For example, by the year 2013 approximately 240 services have been electronized - there have been developed e-services in health, education, welfare and social services, as well as a range of services for entrepreneurs (electronic registration of a company and other registry services, State Environmental Service e-services, State Labour Inspectorate eservices, etc.). In the national portal www.latvija.lv in 2013 the inhabitants had access to 61 e-services, but in 2012 the number of e-service operations exceeded 1 million times. The country has an electronic procurement system, which has a constantly growing turnover (for example, in 2012 it was 18.27 million LVL, which is $37 \%$ more than in 2011). There have also been introduced electronic identity cards, which also includes the tools of identification and electronic signature necessary for obtaining e-services [7].

There can be observed significant improvement in indicators of Latvia among other EU Member States, e.g., the use of the internet or search for the information about goods and services in Latvia is close to the average European level (see Table 1).

The inhabitants of Latvia exceed the average EU indicators in reading newspapers online, using Internet bank, uploading a self-constructed content and acquiring online courses [7].
TABLE 1

PROPORTION OF INTERNET USAGE IN LATVIA AND IN THE EU (28 COUNTRIES), 2009 - 2013

\begin{tabular}{|c|c|c|c|c|c|c|}
\hline \multirow[t]{2}{*}{ Indicators $^{1}$} & \multicolumn{5}{|c|}{ Latvia } & \multirow{2}{*}{$\begin{array}{c}\text { EU }(28 \\
\text { countries) }\end{array}$} \\
\hline & 2009 & 2010 & 2011 & 2012 & 2013 & \\
\hline $\begin{array}{l}\text { Individuals } \\
\text { using the } \\
\text { Internet by } \\
\text { place of } \\
\text { use }\end{array}$ & 50 & 56 & 57 & 62 & 70 & 72 \\
\hline $\begin{array}{l}\text { Individuals } \\
\text { who have } \\
\text { never used } \\
\text { the } \\
\text { Internet }\end{array}$ & 31 & 29 & 27 & 24 & 22 & 20 \\
\hline $\begin{array}{l}\text { Individuals } \\
\text { who } \\
\text { regularly } \\
\text { use the } \\
\text { Internet }\end{array}$ & 61 & 62 & 66 & 70 & 71 & 72 \\
\hline $\begin{array}{l}\text { Individuals } \\
\text { who use } \\
\text { the } \\
\text { Internet for } \\
\text { interaction } \\
\text { with public } \\
\text { authorities }\end{array}$ & 30 & 40 & 41 & 47 & 35 & 41 \\
\hline $\begin{array}{l}\text { Individuals } \\
\text { having } \\
\text { ordered } \\
\text { goods or } \\
\text { services } \\
\text { for private } \\
\text { use via the } \\
\text { Internet }\end{array}$ & 19 & 17 & 20 & 27 & 32 & 47 \\
\hline $\begin{array}{l}\text { Level of } \\
\text { Internet } \\
\text { access } \\
\text { households }\end{array}$ & 58 & 60 & 64 & 69 & 72 & 79 \\
\hline
\end{tabular}

According to the data provided by Central Statistical Bureau of Latvia, in $201335 \%$ of the population used the Internet for collaboration with state and public institutions. Almost all of them searched for information in the websites of state and public institutions (34\%). In 2013 the most popular activity in cooperation with state or public institutions was the submission of income tax return, made by $19 \%$ of users, but $23 \%$ of Internet users said that they had chosen other activities to cooperate with state and public institutions. In 2013 the proportion of people who downloaded and submitted application forms electronically to the public authorities was $14.3 \%$, while there were $13 \%$ who had sent them [8]. Thus, Latvia has not yet achieved the objectives set out in the flagship initiative "A Digital Agenda for Europe" of the document "Europe 2020: A strategy for smart, sustainable and inclusive growth" $-25 \%$ of inhabitants who have downloaded and sent application forms electronically to the national authorities.

As it can be seen in Table 1, in comparison with the average level of the European Union Member States (EU 28) there is a relatively low proportion of the 
population of Latvia who use the Internet for ordering goods or services - in 2013 only 32\% (EU 28 - 47\%), however, compared to 2005 it has increased by $27 \%$. The survey data provided by the Central Statistical Bureau of Latvia show that in 2013 most people used the internet for buying clothes and sporting goods (40\% of online shoppers) and event tickets (37\% of online shoppers). There is no significant difference in IT use in regard to gender, but it is revealed in the analysis of shopping habits, such as a product or services ordered online by men and women. Women purchased clothes and sporting goods on the Internet more often than men ( $45 \%$ of online shoppers, or 10 percentage points more than men). By contrast, among men the most popular goods were electronics (prevalence of 20 percentage points), hardware (prevalence of 12 percentage points), shares, insurance policies and other financial services (prevalence of 9 percentage points). Women also like buying household appliances (prevalence of 5 percentage points), event tickets (prevalence of 4 percentage points) and food products (prevalence of 4 percentage points) [8].

Latvia among the Baltic States is between Estonia and Lithuania in terms of IT use, but the opportunity to sell goods or services online on the Internet is used quite little by the residents of Latvia, lagging behind the EU average indicators by 17 percentage points. Only $3 \%$ of Internet users in Latvia apply to doctor's appointment in the institution's website, lagging behind the EU average level by 8 percentage points. A particular example is the Lithuanian and Latvian internet users' activity in using the Internet for telephone calls or video calls, overtaking the EU average level for respectively 36 and 26 percentage points. In 2013 one-third (32\%) of the citizens of Latvia used mobile Internet out of home or work. The residents of Latvia most often used their phones or smartphones for accessing the Internet (23\%). A laptop was also a popular device among population to access the Internet (16\%) [8].

By contrast, the survey data that was obtained at the end of the year 2012 indicates the reasons why the Internet usage among the population of Latvia does not develop so rapidly. The survey data shows that people have a low level of awareness of services available electronically, and distrust in the Internet environment [11]. However, according to the Central Statistical Bureau's data the main reason why people do not use the Internet to submit completed forms to the state, local government or public service providers is the lack of skills or knowledge - it was mentioned by $3.6 \%$ of internet users of the definite group in the last 12- month period. It can be concluded that there is still low proportion of the population of Latvia who use e-services, as well as low usage of ICT opportunities offered in entrepreneurship.

The main consumers' barriers to adaptation of the internet include:
- no noticeable benefits;

- luck of trust;

- security problems;

- lack of skills;

- cost.

These factors mean that there is a significant group in each national population that does not plan to use the Internet at all [2].

E-commerce is definitely one of the industries that has developed most rapidly and has a great potential. This is evidenced by the research carried out by European e-commerce organization in 2014, which proves that Eastern European countries have the largest e-commerce revenue growth - $+47.3 \%$, while for the rest of the European country groups the maximum increase is $22.7 \%$. Viewing Europe as a whole, the e-commerce market is worth more than 300 billion Euros and the Internet economics makes on average $3.5 \%$ of total GDP. However, it must be noted that the Baltic countries are far behind the rest of European countries [5]. For example in 2013 ecommerce in Latvia accounted for $0.67 \%$ of total GDP.

TABLE 2

THE USE OF E- COMMERCE IN ENTREPRENEURSHIP IN LATVIA AND EU (28) FROM 2009 TO 2013

\begin{tabular}{|c|c|c|c|c|c|c|}
\hline Indicators & 2009 & 2010 & 2011 & 2012 & 2013 & $\begin{array}{c}\text { EU (28 } \\
\text { countries) }\end{array}$ \\
\hline $\begin{array}{l}\text { Share of } \\
\text { enterprise } \\
\text { turnover on e- } \\
\text { commerce } \\
\text { Enterprises } \\
\text { having } \\
\text { purchased } \\
\text { online (at least } \\
1 \% \text { ) }\end{array}$ & 5 & 7 & 14 & 14 & 13 & 14 \\
\hline $\begin{array}{l}\text { Enterprises } \\
\text { having } \\
\text { received } \\
\text { orders online } \\
\text { (at least } 1 \% \text { ) }\end{array}$ & 4 & 6 & 9 & 7 & 7 & 14 \\
\hline $\begin{array}{l}\text { Enterprises } \\
\text { using software } \\
\text { solutions }\end{array}$ & 8 & 11 & 11 & 13 & 12 & $19(2012)$ \\
\hline $\begin{array}{l}\text { Enterprises } \\
\text { with fixed } \\
\text { broadband } \\
\text { access }\end{array}$ & 61 & 66 & 82 & 86 & 91 & 90 \\
\hline
\end{tabular}

Source: EUROSTATE data

Analyzing data on e-commerce in entrepreneurship, it can be concluded that during the last five years in Latvia there has been a tendency for improvement in many parameters (see Table 2), but still it lags behind the average level of the European Union Member States (28). In 2013 7\% of companies of Latvia received orders via the Internet (EU average indicator - 14\%) and $7 \%$ of companies used e- 
commerce in entrepreneurship (EU average indicator $14 \%)$.

TABLE 3

THE USAGE OF COMPUTERS AND INTERNET IN ENTERPRISES OF LATVIA

\begin{tabular}{|c|c|c|c|c|}
\hline Indicators & 2007 & 2009 & 2011 & 2013 \\
\hline Computer usage & 93,3 & 93,5 & 95,4 & 97,4 \\
\hline Internet usage & 83,7 & 86,8 & 92,2 & 94,2 \\
\hline Internet website & 37,7 & 42,1 & 53,4 & 55,7 \\
\hline
\end{tabular}

According to the data provided by Central Statistical Bureau of Latvia, the computer and the Internet were most frequently ( $99 \%$ or more) used by medium and large companies (with a staff of 50 and more people). By contrast, $97.1 \%$ of smaller companies (number of employees from 10 to 49) used computers, while $93.3 \%$ - the Internet. This can be explained by the fact that companies of this size quite often used external services for accounting and other documentation. In 2013 the Internet was most frequently used by companies whose basic activity is provision of information and communication services, repair and maintenance of computer and communication equipment, as well as manufacturing of computers, electronic and optical products. The use of the Internet in these sectors has reached $100 \%$. By contrast, the organizations that used the Internet the least were administrative and support service organizations, as well as catering services. In these sectors the Internet was used respectively $90.6 \%$ and $89.0 \%$ of the companies. In $201356 \%$ of the companies had their own website, which is 3 percentage points more than in 2012. The proportion of companies, which have their own website, has increased along with the increase in staff. In $201351.6 \%$ of small companies, $74.5 \%$ of medium-sized enterprises and $92.1 \%$ of large companies had their website [9].

According to the data provided by the Central Statistical Bureau, in 2013 the broadband Internet was used by $91.4 \%$ of the companies. The most popular type of the Internet connection in enterprises is a DSL connection that is used by $56.5 \%$ of the companies, but in 2013 the benefits of mobile broadband were used by $32.7 \%$ of the enterprises, but other mobile internet connection $-23.0 \%$ [9].

\section{E-skills}

In Latvia like in other European countries e-skills have become an essential necessity of life and if it is impossible to access or use ICT, it can cause a major obstacle to social integration and personal development. Digital literacy is one of the eight major skills of each individual that is essential in a knowledge-based society. In the Digital Agenda for Europe there is also emphasized the importance of teaching EU citizens to use ICT and digital media [3]. Insufficient level of e-commerce skills among entrepreneurs and the population is as a barrier to economic growth, competitiveness and employment in Latvia and the EU as a whole. According to the EU research it is expected that in $201590 \%$ of all jobs in every sector will require technical skills, including eskills. At the same time only $27 \%$ of EU citizens have a high level of ICT skills, and 25\% - a mid-level skills (In Latvia respectively- 31\% and 30\%) [5]. Only 53\% of the working population in Europe believe that their ICT skills are sufficient to labor market needs [4]. According to the data of the Central Statistical Bureau in 2013 in Latvia computer users' best skills were copying and moving files and folders (82.4\% of computer users), as well as using copying and insertion tools $(77.8 \%)$. By contrast, only $5.9 \%$ of computer users had the skills to write a computer program using a specialized programming language (see Table 4).

TABLE 4

COMPUTER LITERACY IN LATVIA IN 2013

\begin{tabular}{lc}
\hline Skills & $\begin{array}{c}\text { \% of computer users of } \\
\text { the definite group }\end{array}$ \\
\hline Copy or move files and folders & 82,4 \\
$\begin{array}{l}\text { Use Copy and insertion tools } \\
\text { Use basic arithmetic formulas in }\end{array}$ & 77,8 \\
spreadsheet & 58,8 \\
$\begin{array}{l}\text { Compress files } \\
\text { Connect and install new devices }\end{array}$ & 50,4 \\
$\begin{array}{l}\text { Write a computer programme using a } \\
\text { specialized programming language }\end{array}$ & 51,1 \\
$\begin{array}{l}\text { Move files from other devices to your } \\
\text { computer }\end{array}$ & 5,9 \\
$\begin{array}{l}\text { Create electronic presentations with } \\
\text { presentation software }\end{array}$ & 62,2 \\
$\begin{array}{l}\text { Install new or replace old operating } \\
\text { system } \\
\text { None of the activities mentioned above }\end{array}$ & 41,1 \\
\hline
\end{tabular}

Source: Latvia CSP data

In 2013 almost all Internet users (97\%) knew how to use search engines to find information, $76 \%$ of users were able to send e-mails with attached files, but $9 \%$ of Internet users were able to create a website. It is interesting to note that regardless of relatively high level of Internet skills, people have quite light minded attitude towards the security of their personal data - less than one in five Internet users (19\%) has ever changed the web browser security settings [8].

In March 2013 there was organized "The week of eskills 2013" for the fourth consecutive year with the goal to improve e-skills of the population of Latvia, during which 42,690 inhabitants of Latvia took the advantage of the opportunity to acquire information and communication technologies. The week of e-skills was organized by LIKTA together with the Ministry of Environmental Protection and Regional Development and major partners - "Lattelecom" and JSC "RIX Technologies". It was held throughout the country with the participation of 114 regions and cities. Overall there were offered 855 events for 
residents and entrepreneurs. In 2013 the Ministry of Economy, Ministry of Education, Ministry of Welfare, Ministry of Environmental Protection and Regional Development, the Latvian Information and Communications Technology Association and other NGOs signed a cooperation memorandum on the development of "E-skills partnership" in Latvia within the framework of the following action: providing education that meets labour market requirements; attraction of young people to ICT industry; interactive and modern learning process and digital content; educating society about the need for digital literacy, einclusion.

Background for technological change and development in Latvia

Since 50 -ies of the 19th century, academic researchers have been actively discussing the idea that technological change and development is the most powerful force for economic growth. Globalisation has significantly increased the competitive pressure on enterprises in many sectors. Together with other factors like the emergence of new, lower-cost producers, fast- changing demand patterns, increased market fragmentation and shortened product life cycles, the pressure has been forming business environment during the last decades. In such environment innovation becomes crucial for the long-term competitiveness and survival of enterprises. One of the key mainsprings of innovations applying e-business technologies is the increasing of availability of knowledge required to facilitate the innovation process [10], especially in the sphere of information and communication technologies.

During the recent years in Latvia like in other European countries, there can be observed a growing lack of ICT professionals - in Europe every fourth is ICT vacancy, and it is expected that in 2015 Europe will have a shortfall of around 700000 ICT specialists [4]. The lack of ICT professionals is hindering the growth of the sector, improvement of international competitiveness, increase of export and attraction of foreign investors. As it can be seen in Table 5, the number of ICT professionals in Latvia has increased, but still it is not sufficient. According to the data provided by LIKTA there is lack of ICT specialists in Latvia and in the whole Europe and according to LIKTA members' and the ICT sector companies' forecasts they are ready to attract 1000 new specialists a year, while the number of newly trained specialists is determined by the total number of bachelors and engineers, because the person can continue master's and doctoral studies only after previously acquired education, but technicians' (college) level of education allows to carry out rather simple ICT operations. This means that in 2012 there were 688 newly trained specialists $(653$ specialists with a bachelor's degree and 35 engineers), which does not satisfy the demand of the national economy.

TABLE 5

PREPARATION OF ICT PROFESSIONALS IN LATVIA

\begin{tabular}{|c|c|c|c|c|c|c|c|}
\hline $\begin{array}{l}\text { Year/ the } \\
\text { obtained } \\
\text { degree }\end{array}$ & 2000 & 2002 & 2004 & 2006 & 2008 & 2010 & 2012 \\
\hline Technicians & 22 & 38 & 68 & 150 & 178 & 220 & 247 \\
\hline Bachelors & 511 & 501 & 578 & 690 & 585 & 612 & 653 \\
\hline Engineer & 100 & 156 & 148 & 103 & 38 & 51 & 35 \\
\hline Masters & 98 & 183 & 373 & 311 & 311 & 287 & 295 \\
\hline Doctors & 0 & 2 & 6 & 10 & 11 & 4 & 21 \\
\hline Total & 731 & 880 & 1173 & 1264 & 1123 & 1174 & 1251 \\
\hline
\end{tabular}

In order to ensure a stable national economic growth, it is necessary to expand and improve ICT practitioners' and professionals' skills, i.e. the digital skills, with a particular focus on preparation of skilled ICT specialists according to labour market requirements, development of professional ICT programmes and ICT education for adolescents.

In Latvia there is also one of the lowest funding for research and development among the EU Member States, which according to the Central Statistical Bureau in 2011 was $0.70 \%$ of GDP (in comparison in 2010 the EU average indicator was $2.0 \%$ of GDP). It also affects the performance of Latvia in various international assessments. According to the World Intellectual Property Organization (WIPO), Cornell University and INSEAD's report "The Global Innovation Index 2014: The Human Factor in Innovation", Latvia takes the 34th position among all countries, Estonia has got 24th place, but Lithuania 39 th position. Latvia ranks in the 32 nd position among the group of countries with high income, in European region it ranks in the 22 nd position, but innovation efficiency index ranks in the 32 nd place. Latvia has received the lowest evaluation in the categories as follows: "Human capital and research" (34.1 points) and "Knowledge \& technology output" (36.8 points) $[13,14]$. In general, it can be concluded that the lack of ICT professionals and low level of funding for research and development in the future could seriously affect the national growth, technological change and development in Latvia, which is an essential factor in the development of electronic commerce.

The most essential problems that influence the development of e-commerce and ICT in Latvia are as follows:

- lack of skills,

- low trust;

- insufficient investment in infrastructure and networks;

- fragmented digital market;

- lack of interoperability; 
- insufficient research and development.

\section{E-commerce strategies at national level}

The government and the private sector are key partners in the development of e-commerce in any country. The business sector should lead, while governments should support and facilitate (by promoting national e-commerce policy framework and strategies) the development and use of e-commerce and ICT. The national e-commerce and ICT strategies must be carried out according to the economic and social context of each country. At the same time it is important to take into account the international experience and best practices to ensure interoperability and harmonization with the developing global e-commerce and ICT systems.

All relevant factors, for example, awareness of society, access to ICT, physical infrastructure, legal framework, quality of human resources, security and privacy aspects are important for successful national strategies. The key factors are:

- e-leaderships;

- national ICT framework and implementation mechanisms;

- legal framework;

- addressing Digital Divide;

- capabilities of individuals and society, qualified human resources, as well as research and development;

- enhancing SME entrepreneurship.

Basing on the e-commerce development tendencies, main limiting factors and advantages for successful development of the electronic commerce in Latvia, there have been identified key strategies for the development of electronic commerce and ICT at national level:

- the formation of positive environment for ecommerce development: policy and legal framework, infrastructure e.g.;

- further development of e-government: services and e-procurement;

- collaboration between public, academic and private sectors;

- building of human capacity: the awareness at all levels, training and education, development, development of professionals with appropriate knowledge, expertise and skills;

- promotion of interoperable standards and provision of information resources;

- development of sector/ region specific estrategies.

\section{CONCLUSION}

There can be observed significant improvement in indicators of Latvia among other EU Member States, e.g., the use of the internet or search for the information about goods and services in Latvia is close to the average European level. The inhabitants of Latvia exceed the average EU indicators in reading newspapers online, using Internet bank, uploading a self-constructed content and acquiring online courses.

Analysing data on e-commerce in entrepreneurship, it can be concluded that during the last five years in Latvia there has been a tendency for improvement in many parameters, but still it lags behind the average level of the European Union Member States (28).

Digital literacy is one of the eight major skills of each individual that is essential in a knowledge-based society.

In order to ensure a stable Latvian economic growth, it is necessary to expand and improve ICT practitioners' and professionals' skills, i.e. the digital skills, with a particular focus on preparation of skilled ICT specialists according to labour market requirements, development of professional ICT programmes and ICT education for adolescents. In Latvia there is one of the lowest funding for research and development among the EU Member States. In general, it can be concluded that the lack of ICT professionals and low level of funding for research and development in the future could seriously affect the national growth, technological change and development in Latvia, which is an essential factor in the development of electronic commerce.

The most essential problems that influence the development of e-commerce and ICT in Latvia are as follows:

- lack of skills,

- low trust;

- insufficient investment in infrastructure and networks;

- fragmented digital market;

- lack of interoperability;

- insufficient research and development.

Basing on the e-commerce development tendencies, main limiting factors and advantages for successful development of the electronic commerce in Latvia, there have been identified key strategies for the development of electronic commerce and ICT at national level: (1) policy and legal framework, infrastructure e.g.; (2) further development of egovernment; (3) collaboration between public, academic and private sectors; (4) building of human capacity; (5) promotion of interoperable standards and provision of information resources; (6) development of sector/ region specific e- strategies.

\section{REFERENCES}

[1] AKMAI'S State of the Internet. Q 12014 Report, Volume 7, $\begin{array}{lllll}\text { Number } & 1 . & 44 & \text { p. } & \text { Available: }\end{array}$ http://www.akamai.com/d1/akamai/akamai-sotiq114.pdf?WT.mc_id=soti_Q114, [Accessed October 2, 2014].

[2] Chaffey, D. (2007) E- Business and E- Commerce Management. Third Edition. FT Prentice Hall. 663 p.

[3] Digital Agenda: Commission outlines action plan to boost Europe's prosperity and well-being.European Commission IP/10/581 19/05/2010. Available: 
http://europa.eu/rapid/press-release IP-10-

581 en.htm?locale=en, [Accessed October 22, 2014].

[4] Digital Agenda Scoreboard 2012, Available: https://ec.europa.eu/digital-agenda/sites/digitalagenda/files/KKAH12001ENN-PDFWEB_1.pdf, [Accessed October 22, 2014].

[5] European B2C E-commerce Report 2014. 63.p. Available: www.ecommerce-europe.eu, [Accessed October 24, 2014].

[6] IDC White Paper Post Crisis: e-Skills are needed to drive Europe's innovation society, 2009. Available: http://ec.europa.eu/enterprise/sectors/ict/files/idc_wp_novemb er 2009 en.pdf, [Accessed November 12, 2014].

[7] Informācijas sabiedrības att̄̄stības pamatnostādnes 2014.2020.gadam. (2013) Available: http://www.varam.gov.lv/lat/ darbibas veidi/e parv/InfSab/?doc $=12668 \quad$ [Accessed November3, 2014].

[8] Informācijas un komunikāciju tehnologiiju lietošana mājsaimniecībās 2013.gadā. Informatīvais ziņojums. Available: http://www.csb.gov.lv, [Accessed October 22, 2014].

[9] Informācijas un komunikāciju tehnolog̣iju lietošana un ekomercija uzṇēmumos 2013.gadā. Informatīvais ziṇojums. Available: http://www.csb.gov.lv/sites/default/files/nr_37_informacijas_u n komunikacijas tehnologiju lietosana un ekomercija_uznemumsos_2013_13_00_lv.pdf, October 24, 2014].

[10] Kar, M. (2009) Product and Service Innovation. In: EBusiness: Management Perspectives. Edited by Reynolds, J. Online resource centre, Oxford. (270-3030) 496 p.

[11] Sabiedriskās domas izvērtējums par e-pakalpojumu pielietojumu Latvijā. 2012.gada decembris. Available: http://www.varam.gov.lv/lat/publ/petijumi/pet_Eparv/?doc=14 321 [Accessed October 25, 2014].

[12] Savrul, M., Cüneyt Kılıç, C. E-Commerce As An Alternative Strategy In Recovery From The Recession. Procedia Social and Behavioral Sciences 24 (2011) 247-259. Available: http://www.sciencedirect.com/science/article/pii/S1877042811 015837 [Accessed October 24, 2014].

[13] The Global Innovtion Index: The Human Factor in Innovation. (2014) Cornell University, INSEAD, and WIPO. Fontainebleau,Ithaca, and Geneva. 429 p. Available: http://www.wipo.int/edocs/pubdocs/en/economics/gii/gii_201 4.pdf, [Accessed October 27, 2014]. 